\title{
UJI EFEK DAUN ILER (Coleus atropurpureus [L.] Benth.) TERHADAP PENYEMBUHAN LUKA INSISI PADA KULIT KELINCI (Oryctolagus cuniculus)
}

\author{
${ }^{1}$ Rudianto Tari \\ ${ }^{2}$ Jimmy Posangi \\ ${ }^{2}$ P. M. Wowor
}

\author{
${ }^{1}$ Kandidat Skripsi Fakultas Kedokteran Universitas Sam Ratulangi \\ ${ }^{2}$ Bagian Farmakologi dan Terapi Fakultas Kedokteran Universitas Sam Ratulangi \\ Email: rudianto.delon@yahoo.com
}

\begin{abstract}
Indonesia has a lot of herbs. One of the well-known and frequently used by people is miana. Empirical experience showed that miana is used to healing wounds. The chemical substances of miana leaves such as essential oil, flavonoid, tanin, and other active substances are expected to involved in the process of wound healing. The purpose of this reseach is to find out the healing effect of miana leaves to the insicion wound on rabbits' skin. This research used an experimental method by using 5 rabbits as the experimental animals. Skin insicions were generated over rabbits' left and right back by $5 \mathrm{~cm}$ each. The wound on the left back is given miana leaves, and the wound on the right back without miana leaves. The wound healing was observed on third, seventh and fourteenth day, with the length, the superficial and the edges of the wounds as the evaluation criteria. The incision wounds on the rabbits' back that given miana leaves are dry and heal faster than the rabbits without miana leaves. Using miana leaves for the rabbits' insicion wounds can speed up the wound healing process.
\end{abstract}

Keywords: miana leaves, wound healing, insicion wound.

\begin{abstract}
Abstrak: Indonesia memiliki banyak tanaman yang berkhasiat obat. Salah satu tanaman yang berkhasiat, dikenal, dan digunakan masyarakat yaitu tumbuhan iler. Pengalaman empiris menunjukkan tumbuhan iler digunakan sebagai obat luka. Kandungan kimia daun iler seperti minyak atsiri, flavonoid, tanin, dan zat-zat aktif lainnya diduga terlibat dalam penyembuhan luka. penelitian ini bertujuan untuk mengetahui efek penyembuhan daun iler terhadap penyembuhan luka insisi pada kulit kelinci. Penelitian ini menggunakan metode eksperimental, dengan menggunakan lima ekor kelinci sebagai hewan uji. Kelinci diinsisi pada punggung kiri dan kanan sepanjang $5 \mathrm{~cm}$. Luka pada punggung kiri diberi daun iler, sedangkan luka pada punggung kanan tidak diberi daun iler. Penyembuhan luka diamati pada hari ke-3, 7, dan 14, dengan kriteria penilaian panjang, permukaan dan tepi luka. Luka insisi pada kulit kelinci yang diberi daun iler terlihat lebih cepat kering dan menutup dibandingkan dengan luka yang tidak diberi daun iler. Pemberian daun iler pada luka insisi kulit kelinci dapat mempercepat proses penyembuhan luka.
\end{abstract}

Kata Kunci: daun iler, penyembuhan luka, luka insisi.

Indonesia kaya akan berbagai jenis tanaman yang memiliki khasiat sebagai obat, diantaranya jenis buah-buahan, sayursayuran, tanaman pangan, rempah-rempah, maupun tanaman yang tumbuh liar di sekitar kita. ${ }^{1}$ Salah satu tumbuhan yang berkhasiat obat, dikenal, dan digunakan masyarakat yaitu tumbuhan iler dari suku lamiaceae. Tumbuhan ini mempunyai khasiat untuk meredakan rasa nyeri, 
sebagai antiinflamasi, antioksidan, antimikroba, antibakteri, dan dapat mempercepat penyembuhan luka. ${ }^{2-4}$

Pengalaman empiris menunjukkan tumbuhan iler dapat digunakan sebagai obat luka dengan cara membubuhkan ulekan daun iler pada luka tersebut. Berdasarkan penelitian sebelumnya telah dilakukan analisis fitokimia terhadap ekstrak daun iler, hasil analisis menunjukkan kandungan kimia daun iler seperti minyak atsiri, flavonoid, tanin, dan zat aktif lainnya. Kandungan kimia tersebut diduga dapat mempercepat penyembuhan luka. ${ }^{2,5}$

Luka merupakan salah satu keadaan yang sering dialami manusia yang terjadi pada kulit dan menimbulkan trauma bagi penderitanya. ${ }^{6}$ Luka adalah kerusakan kontinuitas kulit, mukosa, membran dan tulang atau organ tubuh lain yang dapat terjadi ketika kulit terpapar suhu atau $\mathrm{pH}$, zat kimia, gesekan, trauma tekanan, dan radiasi. ${ }^{7}$

Penyembuhan luka merupakan proses kompleks dan sistematis yang dibagi dalam tiga fase penyembuhan, yaitu inflamasi, proliferasi, dan remodeling. Penyembuhan luka terkait dengan regenerasi sel sampai fungsi organ tubuh kembali pulih, ditunjukkan dengan tanda-tanda dan respon yang berurutan dimana sel bersama-sama berinteraksi, melakukan tugas dan berfungsi secara normal. Tujuan utama penatalaksanaan luka yaitu mencapai penyembuhan yang cepat, fungsi optimal, dan hasil bagus. Penemuan agen penyembuh luka yang efisien dan efektif diperlukan untuk mempercepat proses penyembuhan luka., ${ }^{6,9}$

Tujuan penelitian ini untuk mengetahui efek pemberian daun iler terhadap penyembuhan luka insisi pada kulit kelinci.

\section{METODOLOGI PENELITIAN}

Penelitian ini menggunakan metode eksperimental dengan menggunakan hewan uji penelitian 5 ekor kelinci dewasa.

Penelitian ini dilakukan di laboratorium Farmakologi dan Terapi Fakultas Kedokteran Universitas Sam Ratulangi. Penelitian ini dilaksanakan sejak bulan September 2012 sampai bulan Januari
2013. Bahan dan alat yang digunakan antara lain: kandang kelinci dan perlengkapannya, untuk perlakuan hewan uji (pisau bedah, jarum suntik/disposable, kapas, sarung tangan, plester, kasa), untuk membuat ulekan daun iler (lesung), untuk pengamatan dan pengukuran luka (kamera, meteran), makanan kelinci (kangkung dan wortel), daun iler, alkohol 70\%, lidokain $\mathrm{HCl}$, aquades. Pembuatan luka dilakukan pada punggung kelinci. Rambut di punggung kanan dan kiri dicukur secara hatihati. Daerah yang sudah dicukur kemudian dicuci dengan alkohol 70\% dan dilakukan enestesi dengan lidokain $\mathrm{HCl} 2 \%$ yang diencerkan dengan aquades dengan perbandingan 1:3. Luka insisi dibuat pada daerah punggung kanan dan kiri menggunakan pisau bedah, masing-masing luka dengan panjang $5 \mathrm{~cm}$. Luka tidak dijahit.

Digunakan daun iler muda sebanyak 10 lembar yang dibersihkan dengan air mengalir kemudian diulek dengan menggunakan lesung, ulekan daun iler ditempel pada daerah luka di punggung kiri kelinci, segera setelah dibuat perlakuan. Pemberian ulekan daun iler 1 kali sehari yaitu pada pagi hari.

Luka pada pumggung kanan tidak diberi ulekan daun iler dan hanya dituutp dengan kasa untuk melihat penyembuhan luka secara alamiah. Luka pada punggung kiri diberi ulekan daun iler dengan 1 kali pemberian sehari dan dituutp dengan kasa untuk melihat penyembuhan luka setelah diberi ulekan daun iler. Perkembangan penyembuhan luka insisi ini, diamati setiap hari selama 2 minggu.

\section{HASIL PENELITIAN}

\section{Perbandingan penyembuhan luka kulit kelinci}

Pengamatan penyembuhan luka kulit kelinci A, B, C, D, dan E dimulai dari ke-1 sampai hari ke-14, luka pada kelinci A mulai mengering pada hari ke-2 dan ke-3. Luka semakin memendek dan mulai hilang sejak hari ke-12 pada luka kulit kelinci B dan $\mathrm{D}$ yang diberi perlakuan daun iler 
Tabel 1. Perbandingan penyembuhan luka dengan kriteria penilaian panjang luka kulit kelinci (cm)

\begin{tabular}{|c|c|c|c|c|c|c|c|c|c|c|c|}
\hline \multirow{2}{*}{$\begin{array}{c}\text { Hari } \\
\text { ke- }\end{array}$} & \multirow{2}{*}{ Tanggal } & \multicolumn{2}{|c|}{ Kelinci A } & \multicolumn{2}{|c|}{ Kelinci B } & \multicolumn{2}{|c|}{ Kelinci C } & \multicolumn{2}{|c|}{ Kelinci D } & \multicolumn{2}{|c|}{ Kelinci E } \\
\hline & & Kiri & Kanan & Kiri & Kanan & Kiri & Kanan & Kiri & Kanan & Kiri & Kanan \\
\hline 1 & 9/12/2012 & 5 & 5 & 5 & 5 & 5 & 5 & 5 & 5 & 5 & 5 \\
\hline 2 & 10/12/2012 & $4,5^{*}$ & 4,8 & $4,1^{*}$ & 4,8 & 4,8 & 4,8 & $4,2 *$ & 4,8 & 4,5 & 4,8 \\
\hline 3 & $11 / 12 / 2012$ & 4 & $4,3^{*}$ & 3,8 & $4,2^{*}$ & $4,1 *$ & 4,7 & 4 & $4,6^{*}$ & $4,1^{*}$ & $4,8^{*}$ \\
\hline 4 & $12 / 12 / 2012$ & 3,5 & 4,1 & 3,6 & 3,8 & 3,6 & $4 *$ & 3,8 & 4 & 3,5 & 4 \\
\hline 5 & 13/12/2012 & 3,4 & 3,7 & 3,5 & 3,5 & 2,9 & 3,2 & 3,6 & 3,6 & 3,4 & 3,7 \\
\hline 6 & 14/12/2012 & 3,1 & 3,4 & 3,3 & 3,4 & 2,7 & 2,9 & 3,4 & 3,6 & 3,0 & 3,5 \\
\hline 7 & $15 / 12 / 2012$ & 2,6 & 3 & 3,2 & 3,3 & 2,5 & 2,7 & 3 & 3,3 & 2,9 & 3,3 \\
\hline 8 & 16/12/2012 & 2,2 & 2,7 & 2,9 & 2,8 & 2,4 & 2,7 & 3 & 3,2 & 2,5 & 3,2 \\
\hline 9 & 17/12/2012 & 1,9 & 2,5 & 2,9 & 2,7 & 2,4 & 2,4 & 2,7 & 3 & 2,4 & 3 \\
\hline 10 & 18/12/2012 & 1,4 & 2,2 & 2,8 & 2,7 & 2,2 & 2,4 & 2,3 & 2,5 & 2,3 & 3 \\
\hline 11 & 19/12/2012 & 1,3 & 1,8 & 1,6 & 2,4 & 2 & 2,3 & 1,9 & 2 & 2,0 & 2,8 \\
\hline 12 & 20/12/2012 & 1 & 1,5 & 0 & 1,9 & 2 & 2,2 & 0 & 1,5 & 1,9 & 2,8 \\
\hline 13 & 21/12/2012 & 0,8 & 1,3 & 0 & 1 & 1,5 & 2,2 & 0 & 0,9 & 1,9 & 2,8 \\
\hline 14 & $22 / 12 / 2012$ & 0.5 & 1,2 & 0 & 0,7 & 1,1 & 2,2 & 0 & 0,5 & 1,9 & 2,8 \\
\hline
\end{tabular}

Keterangan: Kiri = luka yang diberi daun iler. Kanan = luka yang tidak diberi daun iler. ${ }^{*}=$ hari pertama luka mengering.

Data yang diperoleh ditunjukkan pada Tabel 1.

\section{Gambaran makroskopik penyembuhan luka kulit kelinci hari ketiga}

Pada pemeriksaan hari ke-3, luka kulit kelinci A yang diberi daun iler memiliki panjang $4 \mathrm{~cm}$, tepi luka belum menyatu, luka terlihat lebih dangkal dibanding saat insisi, permukaan luka mulai mengering, berwarna gelap dan tertutup keropeng. Luka yang tidak diberi daun lebih panjang, yaitu $4,3 \mathrm{~cm}$, tepi luka masih terpisah dan melebar, permukaan dan tepi luka tampak merah dan basah.

Pemeriksaan luka kulit kelinci B pada hari ke-3 memperlihatkan luka yang diberi daun iler yang memiliki panjang $3,8 \mathrm{~cm}$ dengan tepi luka yang sudah mulai menyatu, permukaan luka kering dan berwarna gelap, tertutup keropeng. Pada luka yang tidak diberi daun iler, terlihat panjang luka 4,2 cm dengan tepi luka masih terpisah dan melebar, permukaan luka mulai mengering, tampak berwarna merah dan bengkak.

Pada pemeriksaan hari ke-3, luka kulit kelinci $\mathrm{C}$ yang diberi daun iler terlihat memiliki panjang 4,1 cm, luka terbuka, permukaan luka tampak kekuningan dan mulai mengering namun terlihat lembab, tepi luka sudah mengering dan berwarna gelap. Pada luka yang tidak diberi daun iler, terlihat panjang luka $4,7 \mathrm{~cm}$, luka terbuka, tepi luka masih terpisah dan melebar, permukaan luka tampak kekuningan dan basah.

Luka kulit kelinci D pada pemeriksaan hari ke-3 memperlihatkan luka yang diberi daun iler memiliki panjang $4 \mathrm{~cm}$. Luka terlihat kering dan berwarna gelap, tepi luka mulai menyatu dan tertutup keropeng. Pada luka yang tidak diberi daun iler, panjang luka 4,6 cm, luka mulai mengering dan berwarna merah.

Luka kulit kelinci E pada pemeriksaan hari ke-3 memperlihatkan luka yang diberi daun iler memiliki panjang 4,1 cm, permukaan luka kering dan berwarna gelap. Pada luka yang tidak diberi daun iler terlihat panjang luka 4,8 cm dengan luka terbuka, permukaan luka basah dan tampak pucat.

\section{Gambaran makroskopik penyembuhan luka kulit kelinci hari ketujuh}

Pada pemeriksaan hari ke-7, luka kulit kelinci A yang diberi daun iler memiliki panjang 2,6 cm, luka semakin mengecil, terlihat luka kering dan berwarna gelap, tertutup keropeng, tepi luka kering mengeras. Pada luka yang tidak diberi daun iler panjang $3 \mathrm{~cm}$, terlihat luka sudah mengering, tepi luka masih terpisah. 
Pemeriksaan hari ke-7 pada luka kulit kelinci B menunjukkan luka yang diberi daun iler memiliki panjang 3,2 cm dengan permukaan luka kering, luka tertutup keropeng, tepi luka menyempit. Pada luka yang tidak diberi daun iler, panjang $3,3 \mathrm{~cm}$, permukaan luka kering dan tampak merah.

Pemeriksaan hari ke-7 pada luka kulit kelinci C menunjukkan luka yang diberi daun iler dengan panjang luka 2,5 cm, permukaan luka kering, kedalaman luka berkurang. Pada luka yang tidak diberi daun iler, dengan panjang luka $2,7 \mathrm{~cm}$, permukaan luka kering, luka belum menyatu.

Pada pemeriksaan hari ke-7 luka kulit kelinci D, terlihat luka yang diberi daun iler memiliki panjang $3 \mathrm{~cm}$, permukaan tertutup keropeng, tepi luka mulai menyatu. Luka kulit kelinci yang tidak diberi daun iler, menunjukkan panjang luka $3,3 \mathrm{~cm}$, permukaan luka sudah mengering namun masih tampak merah.

Pemeriksaan hari ke-7 pada luka kulit kelinci $\mathrm{E}$ menunjukkan luka yang diberi daun iler memiliki panjang 2,9 cm dengan luka kering dan tertutup keropeng dan tumpukan daun iler yang mengering. Pada luka yang tidak diberi daun iler panjang luka 3,3 cm, luka kering dan tampak pucat.

\section{Gambaran makroskopik penyembuhan luka kelinci hari keempat belas}

Pemeriksaan hari ke-14 pada luka kulit kelinci A menunjukkan luka yang diberi daun iler memiliki panjang 0,6 cm, luka semakin mengecil. Luka yang tidak diberi daun iler panjang $1,1 \mathrm{~cm}$.

Pada pemeriksaan hari ke-14 luka kulit kelinci B, luka yang diberi daun iler telah menutup sempurna, keropeng sudah lepas, pada luka ini tertinggal gambaran bekas luka berwarna pucat. Pada luka yang tidak diberi daun iler, masih terlihat luka $0,7 \mathrm{~cm}$.

Pada pemeriksaan hari ke-14 luka kulit kelinci $\mathrm{C}$ menunjukkan luka yang diberi daun iler dengan panjang luka 1,1 cm, luka sebagian masih tertutup keropeng, sebagian keropeng sudah ada yang terlepas. Pada luka yang tidak diberi daun iler panjang luka 2,2 cm dengan luka kering.
Pemeriksaan hari ke-14 pada luka kulit kelinci D, luka yang diberi daun iler terlihat sudah menutup sempurna, keropeng sudah terlepas semua, dan tidak berbekas, luka sudah mulai ditumbuhi bulu. Pada luka yang tidak diberi daun iler masih terlihat luka kecil $0,5 \mathrm{~cm}$.

Pada pemeriksaan hari ke-14 luka kulit kelinci E, luka yang diberi daun iler dengan panjang luka 1,9 cm, luka kering, pada celah insisi terdapat tumpukan daun iler yang mengering dan menempel yang membentuk kerak pada luka. Luka pada kulit kelinci yang tidak diberi daun iler dengan panjang luka 2,8 cm, luka kering, tampak pucat.

\section{BAHASAN}

Penelitian ini bertujuan untuk mengetahui efek pemberian daun iler terhadap penyembuhan luka insisi pada kulit kelinci. Penelitian ini dilakukan untuk melihat perbedaan gambaran makroskopik pada luka yang diberi perlakuan daun iler dengan luka tanpa diberi perlakuan daun iler.

Pada pengamatan penyembuhan luka pada kulit kelinci, 24 jam setelah terjadi luka, ruang insisi segera terisi oleh bekuan darah yang membentuk keropeng yang menutupi dan melindungi tempat penyembuhan, sehingga dapat mencegah agen infeksi yang dapat menghambat laju penyembuhan luka. ${ }^{8}$ Kandungan kimia daun iler seperti flavonoid, ${ }^{2}$ tanin, dan minyak atsiri juga bersifat sebagai antiseptik, ${ }^{10}$ yang dapat menghambat pertumbuhan bakteri, sehingga luka yang diberi daun iler lebih cepat mengering, yaitu pada hari kedua dan ketiga.

Berdasarkan kepustakaan bahwa pada 48 jam setelah terjadi luka, secara mikroskopik terjadi pembentukan jaringan granulasi, pembentukan pembuluh darah baru, dan proliferasi fibroblas serta gambaran makroskopiknya terlihat berwarna merah muda, lembut dan bergranula seperti yang terlihat pada penelitian hari ketiga penyembuhan luka. ${ }^{8}$ Penyembuhan luka kulit kelinci dengan pemberian daun iler yang diduga mengandung flavonoid lebih 
cepat dibandingkan luka tanpa pemberian daun iler karena flavonoid dapat meningkatkan proses mitogenesis, interaksi sel, meningkatkan vaskularisasi, mencegah nekrosis sel, dan penyembuhan jaringan luka. ${ }^{11,12}$

Pada hari ketujuh, gambaran makroskopik penyembuhan luka insisi kulit kelinci memperlihatkan kedalaman dan panjang luka yang berkurang, hal ini disebabkan oleh epitel tepi luka yang terdiri dari sel basal yang terlepas dari dasarnya dan berpindah mengisi permukaan luka. ${ }^{6,8}$ Pada luka kulit kelinci yang diberi daun iler panjang luka dan kedalaman luka berkurang lebih cepat dibanding luka yang tidak diberi daun iler. Begitu pun juga dengan penyatuan tepi luka, luka kulit kelinci yang diberi daun iler lebih cepat memperlihatkan penyatuan tepi luka.

Berdasarkan kepuskataan bahwa pada hari keempat belas terjadi penumpukan kolagen dan proliferasi fibroblas yang berlanjut. Infiltrasi leukosit, edema, dan peningkatan vaskularitas telah berkurang, proses pemutihan dimulai, dilakukan melalui peningkatan deposisi kolagen di dalam jaringan parut bekas insisi dan regresi saluran pembuluh darah. Saat jaringan parut menjadi matang, akhirnya regresi pembuluh darah akan mengubah jaringan granulasi yang sangat banyak pembuluh darahnya menjadi suatu jaringan parut yang pucat dan sangat avaskular. ${ }^{8}$ Hal ini terlihat pada luka kulit kelinci B dan D yang diberi daun iler menunjukkan gambaran luka yang rata, tipis, dan hanya terlihat garis putih. Luka kulit kelinci A, C, dan $\mathrm{E}$ yang diberi daun iler juga memperlihatkan percepatan penyembuhan dibandingkan dengan luka tanpa pemberian daun iler. Hal ini disebabkan oleh kandungan flavonoid pada daun iler yang berperan pada kontraksi luka dan peningkatan epitelisasi. ${ }^{13}$

\section{SIMPULAN}

Pemberian daun iler pada luka insisi kulit kelinci dapat mempercepat proses penyembuhan luka.

\section{SARAN}

Perlu penelitian lebih lanjut tentang efek pemberian daun iler terhadap penyembuhan luka dengan pengujian dosis, penambahan jumlah sampel, dan penambahan parameter kontrol seperti povidone iodine, Perlu ditambahkan pemeriksaan mikroskopik pada penelitian selanjutnya untuk melihat efek pemberian daun iler terhadap penyembuhan luka secara mikroskopik, dan Perlu dilakukan penelitian lebih lanjut mengenai pemberian daun iler terhadap penyembuhan luka insisi kulit kelinci dalam bentuk ekstrak, gel atau salep.

\section{UCAPAN TERIMA KASIH}

Ucapan terima kasih disampaikan pada dr. Lily loho, $\operatorname{SpPA}(\mathrm{K})$ dan dr. Jane wuisan, MS, SpFK dan pada semua pihak pihak yang baik secara langsung maupun tidak langsung telah menimbulkan ide atau gagasan dalam pemikiran penulis sehingga dapat menyelesaikan artikel ini.

\section{DAFTAR PUSTAKA}

1. Kusuma FR, Zaky BM. Tumbuhan Liar Berkhasiat Obat. Jakarta: Agromedia Pustaka, 2005; p.1-7.

2. Rahmawati F. Isolasi dan Karakterisasi Senyawa Antibakteri Ekstrak Daun Miana (Coleus scutellarioides [L.] Benth) [Tesis]. Bogor: Institut Pertanian Bogor; 2008.

3. Dalimartha S. Atlas Tumbuhan Obat Indonesia Jilid 2. Jakarta: Trubus Agriwidya, 2000; p.65-77.

4. Philippine medical plants. Mayana [homepage on the Internet]. Nodate [cited 2012 Oct 18]. Available from: http://www. stuartxchange.org/Mayana.html.

5. Saragih RM. Isolasi Senyawa Flavonoida dari Daun Tumbuhan Iler (Coleus atropurpureus Benth.) [Skripsi]. Medan: Fakultas Matematika dan Ilmu Pengetahuan Alam, Universitas Sumatera Utara; 2011.

6. Ahmadayah I, Prasetyono TOH, Pusponegoro AD. Luka. Dalam: Sjamsuhidajat R, De jong W, editor. Buku Ajar Ilmu Bedah (Edisi Kedua). Jakarta: EGC, 2004; p.67-73.

7. Mansjoer A, Suprohaita, Wardhani WI, 
Setiowulan W, Wicaksono A, Hamsah A, dkk. Kapita Selekta Kedokteran Jilid 2 (Edisi Ketiga). Jakarta: Media Aesculapius, 2000; p.396-403.

8. Mitchell RN, Cotran RS. Pemulihan Jaringan: Regenerasi dan Fibrosis Sel. Dalam: Kumar V, Cotran RS, Robbins SL. Buku Ajar Patologi (Edisi Ketujuh). Jakarta: EGC, 2007; p.65-84.

9. Merchandetti M. Wound Healing and Repair. Emedicine [homepage on the Internet]. 2002 [cited 2012 Oct 17]. Available from: http://emedicine. medscape.com/article/1298129overview\#showall.

10. Ajizah A. Sensitivitas Salmonella Typhimurium Terhadap Ekstrak Daun Psidium guajava L. Bioscientiae. 2004;
1(1):31-8.

11. Syarfati, Eriani K, Damhoeri A. The potential of jarak cina (Jatropa multifida L.) secretion in healing new-wounded mice. Jurnal Natural. 2011;11(1):16-9.

12. Argamula G. Aktivitas sediaan salep ekstrak batang pohon pisang ambon (Musa paradisiaca var sapientum) dalam proses persembuhan luka pada mencit (Mus musculus albinus)[skripsi]. Bogor: Fakultas Kedokteran Hewan, Institut Pertanian Bogor; 2008; p.32-9.

13. Agarawal PK, Singh A, Gaurav K, Goel S, Khanna HD, Goel RK. Evaluation of wound healing activity of extracts of plantain banana (Musa sapientum var. paradisiaca) in rats. Indian Journal of Experimental Biology. Jan 2009;47:38. 